\title{
Računalniški kognitivni trening pri otrocih in mladostnikih z lažjo motnjo v duševnem razvoju
}

\author{
Nastasija Mahne ${ }^{\mathrm{l}^{*}}$, Karin Bakračevič² in Vojko Kavčič $\mathfrak{c}^{3,4}$ \\ ${ }^{1}$ Zdravstveni dom Kočevje \\ ${ }^{2}$ Oddelek za psihologijo, Filozofska Fakulteta, Univerza v Mariboru \\ ${ }^{3}$ Institute of Gerontology, Wayne State University, Detroit, ZDA \\ ${ }^{4}$ Mednarodni inštitut za aplikativno gerontologijo, Ljubljana
}

\begin{abstract}
Povzetek: Več študij je preučevalo bližnje in daljne transferne učinke kognitivnega treninga (predvsem treninga delovnega spomina), a je bilo le malo študij narejenih na populaciji otrok z lažjo motnjo v duševnem razvoju. Iz tega razloga smo želeli v naši raziskavi preveriti, kakšne učinke ima računalniški kognitivni trening - virtualni labirint - na kognitivne funkcije otrok $\mathrm{z}$ lažjo motnjo $\mathrm{v}$ duševnem razvoju. V raziskavi so nas še posebej zanimali učinki treninga na izvršilne funkcije in nekatere z njimi povezane kognitivne funkcije: preklapljanje med mentalnimi seti, verbalno fluentnost, delovni spomin, dolgotrajni spomin in hitrost procesiranja. V raziskavi je sodelovalo 21 učencev, $11 \mathrm{v}$ eksperimentalni in $10 \mathrm{v}$ kontrolni skupini. Vključili smo učence od 4. do 9. razreda, stari so bili od 10 do 19 let. Eksperimentalna skupina je trening izvajala 12-krat po 35 minut. Intervencija je potekala skupinsko, dvakrat na teden. Kontrolna skupina je bila pasivna in ni izvajala nobenih aktivnosti. Pred in po končanih treningih smo udeležence v kontrolni in eksperimentalni skupini testirali z nevropsihološkimi testi in računalniško baterijo CogState. Rezultati so pokazali pomembne izboljšave pri eksperimentalni skupini v primerjavi s kontrolno skupino na Reyjevem slušno-verbalnem testu (s katerim preverjamo kognitivne sposobnosti na področju slušno-besednega spomina), pri meri skupnega števila priklicanih besed (vsoti preizkusov od I do III) ter na preizkusu po interferenci (preizkusu IV). Pomembne izboljšave pri eksperimentalni skupini v primerjavi s kontrolno pa so se pokazale tudi pri Testu povezovanja - delu A, ki preverja motorično hitrost. Najmočnejši je bil torej učinek treninga na hitrost procesiranja vidnih informacij in besedni spomin.
\end{abstract}

Ključne besede: računalniški kognitivni trening, otroci z lažjo motnjo v duševnem razvoju, izvršilne funkcije, spomin, hitrost procesiranja informacij

\section{Computerised cognitive training in pupils with mild intellectual disability}

\author{
Nastasija Mahne ${ }^{1^{*}}$, Karin Bakračevič² and Vojko Kavčič $\check{c}^{3,4}$ \\ 'Public medical center Kočevje, Slovenia \\ ${ }^{2}$ Department of Psychology, Faculty of Arts, University of Maribor, Slovenia \\ ${ }^{3}$ Institute of Gerontology, Wayne State University, Detroit, USA \\ ${ }^{4}$ International Institute of Applied Gerontology, Ljubljana, Slovenia
}

\begin{abstract}
A lot of studies investigated near and far transfer effects of cognitive training (especially working memory training), but only few were carried out on children with mild intellectual disability. For this reason, we wanted to study the effects of computerised cognitive training (using virtual labyrinth) on cognitive functions of children with mild intellectual disability. We were particularly interested in its effects on executive functions and the related cognitive functions: shifting, verbal fluency, working memory, longterm memory and processing speed. Twenty-one fourth to ninth graders aged 10 to 19 participated, 11 in the experimental and 10 in the control group. The experimental group participated in 12 training sessions, each lasting 35 minutes. Intervention took place in groups, twice a week. The control group was passive and was not involved in any activities. Before and after trainings both groups were tested with selected neuropsychological tests and the CogState computer battery. The results showed that in the second wave, the experimental group considerably improved its results on several measurements of cognitive functions. Compared to the control group, experimental group showed significantly higher total gains on the Rey Auditory Verbal Learning Test (AVLT; total score and test IV score) and the Trail Making Test, Part A. The training therefore had the largest effect on the speed of processing visual information and verbal memory.
\end{abstract}

Key words: computerised cognitive training, children with mild intellectual disability, executive functions, memory, processing speed

"Naslov/Address: Nastasija Mahne, Zdravstveni dom Kočevje, Roška cesta 18, 1330 Kočevje, e-mail: nastasija.mahne@gmail.com

Članek je licenciran pod pogoji Creative Commons Attribution 4.0 International licence. (CC-BY licenca).

The article is licensed under a Creative Commons Attribution 4.0 International License (CC-BY license). 
Motnja v duševnem razvoju je nevrološko pogojena razvojna motnja, ki se kaže v pomembno nižjih sposobnostih ter pomembnih odstopanjih prilagoditvene spretnosti. Stopnja motnje je definirana tako na osnovi skupnega IQ rezultata kot tudi na osnovi ugotovljenih prilagoditvenih funkcij. Skupaj $\mathrm{z}$ motnjo v duševnem razvoju se lahko pojavljajo tudi druge razvojne motnje (Marinč idr., 2015).

Za otroke $z$ lažjo motnjo v duševnem razvoju je značilno, da imajo kratkotrajno pozornost in koncentracijo. Še posebej je to opazno pri kompleksnih nalogah, kjer hitro obupajo (Barič, 2009). Miselni procesi v večji meri potekajo na konkretni ravni. $\mathrm{Ob}$ individualnem pristopu in prilagoditvah lahko ti otroci dosežejo temeljna šolska znanja, ki ne zadostujejo minimalnim standardom znanja, ter se usposobijo za manj zahtevno poklicno delo in samostojno socialno življenje. Znižane imajo tudi sposobnosti za načrtovanje, odločanje, organizacijo in izvedbo dejavnosti (Marinč idr., 2015). Preučevanje izvršilnih funkcij, kamor spadajo tudi naštete funkcije, je pri otrocih $\mathrm{z}$ lažjo motnjo $\mathrm{v}$ duševnem razvoju še posebej zanimivo, saj več raziskovalcev poroča o povezanosti izvršilnih funkcij $\mathrm{z}$ inteligentnostjo (npr. Carpenter idr., 1990; Miyake idr., 2001; Salthouse idr., 1998).

Izvršilne funkcije predstavljajo kompleksen pojem, tesno povezan s spominom in pozornostjo, ki ga težko opredelimo $z$ eno definicijo (Dawson in Guare, 2009). Metafora za opis izvršilnega delovanja je, da je to dirigent simfoničnega orkestra. Ne glede na to, kako dobro glasbeniki v simfoničnem orkestru igrajo svoje instrumente, verjetno ne bodo ustvarili dobre simfonične glasbe, če ne bodo imeli dirigenta, ki bo izbral, kaj bo kdo igral, povedal, kdaj začeti, spreminjal hitrost in glasnost vsake sekcije ter dosegel, da bodo različni instrumenti zaključili z igranjem ob primernem času. Čeprav lahko vsak glasbenik igra svoj instrument spretno, subtilno, dinamično, je integrirano funkcioniranje orkestra $\mathrm{v}$ veliki meri odvisno od dirigentovega usklajevanja in upravljanja funkcij (Brown, 2005). Obstajajo različni modeli izvršilnih funkcij, ki jih opisujejo različni raziskovalci. Dawson in Guare (2009) opisujeta izvršilne funkcije, ki temeljijo bolj na vedenju (inhibicija odzivanja, emocionalna kontrola, vzdrževanje pozornosti, začenjanje z aktivnostjo, fleksibilnost, ciljno usmerjena vztrajnost), in izvršilne funkcije, ki vključujejo bolj kognicijo kot vedenje (načrtovanje, organiziranje, upravljanje s časom, delovni spomin, metakognicija).

V preteklosti je bilo narejenih kar nekaj študij, ki so preučevale učinke kognitivnega treninga pri različnih skupinah otrok s posebnimi potrebami, predvsem pri otrocih $\mathrm{z}$ ADHD, otrocih $\mathrm{z}$ disleksijo in otrocih $\mathrm{z}$ avtističnimi motnjami, učinke pri otrocih $\mathrm{z}$ lažjo motnjo $\mathrm{v}$ duševnem razvoju pa je preučevalo manj študij. Söderqvist idr. (2012) so pri otrocih z IQ pod 70, starih 6 do 12 let, prišli do ugotovitev, da so najmočnejši napovedniki napredovanja pri treningu spol, komorbidnost in izhodiščna zmogljivost delovnega spomina. Večji napredek se je pokazal še zlasti pri dekletih brez dodatnih diagnoz in $\mathrm{z}$ večjo izhodiščno zmogljivostjo delovnega spomina. Čeprav je trening zajemal samo vidnoprostorske naloge, je privedel do izboljšav pri nalogah, ki ocenjujejo verbalni delovni spomin in jezikovne funkcije, kar kaže na prenos učinkov treninga med kognitivnimi konstrukti in modalitetami. Pri nalogah, ki preverjajo sposobnost sklepanja, pa ni prišlo od statistično značilnih izboljšav. Po enem letu ni bilo vidnih statistično značilnih učinkov treninga, kar nakazuje na to, da bi moral biti trening bolj intenziven ali ponavljajoč, da bi učinki pri otrocih z motnjo v duševnem razvoju vztrajali. Pri dlje časa trajajočih treningih naj bi bil tudi obseg transferja večji (Bergman Nutley idr., 2011).

Van der Molen idr. (2010) pa so preučevali učinkovitost računalniškega treninga delovnega spomina pri adolescentih, starih med 13 in 16 let, $\mathrm{z}$ motnjo $\mathrm{v}$ duševnem razvoju in IQ med 55 in 85 . V primerjavi s kontrolno skupino se je $\mathrm{v}$ skupini, ki je bila vključena $\mathrm{v}$ adaptiven trening, od testiranja pred do testiranja po intervenciji statistično značilno bolj povečal verbalni kratkotrajni spomin. Pomemben učinek na verbalni kratkotrajni spomin se je pokazal tudi pri kasnejšem testiranju (10 tednov po končanem treningu), pri katerem so se pokazali učinki še na drugih področjih. Tako udeleženci, ki so obiskovali adaptiven trening, kot tisti, ki so obiskovali neadaptivnega, so v primerjavi s kontrolno skupino dosegali višje rezultate pri kasnejšem testiranju kot pri takojšnjem testiranju po intervenciji, in sicer pri nalogah vidnega kratkotrajnega spomina, računanju in priklicu zgodbe. Večje učinke pri kasnejšem testiranju $\mathrm{v}$ primerjavi s testiranjem takoj po intervenciji so opažali tudi drugi avtorji (Holmes idr., 2009; Klingberg idr., 2005; van't Hooft idr., 2007). Računanje in priklic zgodbe sta se pri skupini z adaptivnim in neadaptivnim treningom statistično značilno povečala $\mathrm{v}$ času med testiranjem pred intervencijo ter testiranjem deset tednov po intervenciji. Poleg tega je skupina, ki je izvajala neadaptivni trening, pokazala statistično značilno povečanje kapacitete vidno-prostorskega delovnega spomina. V študiji ni bilo ugotovljenih pozitivnih učinkov na verbalni delovni spomin. To je v nasprotju z rezultati študije Thorella idr. (2009) ter Söderqvista idr. (2012), ki so našli učinke prenosa treninga vidno-prostorskega delovnega spomina na verbalni delovni spomin. Ta študija ravno tako kot prejšnja (Söderqvist idr., 2012) ni ugotovila učinkov treninga na fluidno inteligentnost in inhibicijo. Presenetljivo je, da so bili učinki adaptivnega in neadaptivnega treninga $\mathrm{v}$ tej študiji podobni. To je $\mathrm{v}$ nasprotju s prejšnjimi študijami, ki so kazale večje učinke adaptivnega treninga $\mathrm{v}$ primerjavi $\mathrm{z}$ neadaptivnim (Holmes idr., 2009; Klingberg idr., 2005), a so vključevale netipično razvijajoče se otroke bodisi z majhno kapaciteto delovnega spomina bodisi z ADHD. Van der Molen idr. (2010) navajajo, da obstaja možnost, da niso našli razlik, ker so v raziskavo vključili otroke $\mathrm{z}$ nižjim IQ in je bil trening morda manj intenziven. Kljub temu da so se pokazale izboljšave na več področjih, so bili učinki velikosti večinoma majhni, kar je verjetno posledica nizke intenzivnosti treninga.

Cilj raziskave Delavariana idr. (2015) je bil oblikovati računalniški program $\mathrm{v}$ obliki igre za trening delovnega spomina pri otrocih $\mathrm{z}$ lažjo motnjo $\mathrm{v}$ duševnem razvoju. Otroci, vključeni v študijo, so bili stari od 9 do 14 let. Rezultati so pokazali statistično značilne razlike $v$ kapaciteti delovnega spomina med otroki z motnjo v duševnem razvoju in tipično razvijajočimi se otroki. Po računalniškem treningu 
delovnega spomina sta se $\mathrm{v}$ eksperimentalni skupini $\mathrm{v}$ primerjavi s kontrolno skupino statistično značilno izboljšala tako slušni kot vidno-prostorski delovni spomin.

Učinki, ki so jih ugotavljale različne študije, se med seboj razlikujejo, zato so se Danielsson idr. (2015) odločili za metaanalizo 10 študij, ki so vključevale (i) testiranje pred in po izvedenem treningu, (ii) eksperimentalno in kontrolno skupino ter (iii) mere delovnega ali kratkotrajnega spomina. Udeleženci v študijah so bili mlajši od 30 let. Rezultati so pokazali statistično značilno, a majhno velikost učinka za trening delovnega spomina pri posameznikih $\mathrm{z}$ motnjo $\mathrm{v}$ duševnem razvoju v primerjavi s kontrolno skupino. Pristop treninga, ki vključuje tako verbalno kot vidno-prostorsko komponento in krepi predvsem področje strategij, je bil edini tip treninga s srednjo velikostjo učinka. S teoretičnega stališča rezultati metaanalize kažejo, da $\mathrm{v}$ primeru, ko upoštevamo posameznike $\mathrm{z}$ motnjo $\mathrm{v}$ duševnem razvoju kot eno skupino, kombiniran trening deluje bolje kot trening, ki se osredotoča le na en vidik delovnega spomina. Avtorji opozarjajo, da lahko kontrolna skupina, ki je vključena $\mathrm{v}$ aktivnosti, ki na nek način vključujejo spomin, zmanjša velikost učinka razlike med eksperimentalno in kontrolno skupino. V njihovo metaanalizo je bilo vključenih kar nekaj takšnih študij (Moalli, 2006; Moalli idr., 2004; Söderqvist idr., 2012; Van der Molen idr., 2010). Interpretacije učinkov kognitivnega treninga pa so vprašljive tudi zaradi majhnega števila študij in razlik med študijami. Zdi se, da imajo različne vrste intervencij različne učinke. Potrebnih bi bilo več študij, da bi bolje razumeli, kako oblikovati učinkovito intervencijo delovnega spomina za to skupino, in da bi razumeli, če in kako se ti kratkoročni učinki odražajo skozi čas in kako se prenašajo v vsakodnevne aktivnosti. Poleg tega so avtorji v metaanalizo vključili posameznike $\mathrm{z}$ različnim IQ, med katerimi so bili tudi otroci z Downovim sindromom. Tudi takšna heterogenost med udeleženci otežuje oblikovanje jasnih zaključkov.

$\mathrm{Na}$ podlagi do zdaj izvedenih študij torej težko oblikujemo zaključke in hipoteze glede vpliva kognitivnega treninga na skupino učencev $\mathrm{z}$ lažjo motnjo $\mathrm{v}$ duševnem razvoju, saj so zajemale različne vrste treningov, merile so različne konstrukte, poleg tega pa $\mathrm{v}$ študije niso bili vključeni le učenci $\mathrm{z}$ lažjo motnjo $\mathrm{v}$ duševnem razvoju, ampak tudi učenci $\mathrm{z}$ večjimi primanjkljaji. V naši raziskavi smo zato želeli preveriti, ali je računalniški kognitivni trening virtualni labirint - primeren za skupino otrok z lažjo motnjo $\mathrm{v}$ duševnem razvoju in kakšne učinke ima pri teh otrocih na izvršilne funkcije in druge kognitivne funkcije, ki so $z$ izvršilnimi funkcijami tesno povezane. Uporabiti smo želeli adaptivni trening, saj je uporaba prilagodljivih algoritmov, ki zagotavljajo, da je stopnja težavnosti nalog za posameznika vedno izziv, ključnega pomena za učinkovitost treninga (Klingberg, 2010). Zanimalo nas je, katera kognitivna področja (če sploh katera) se bodo pri učencih v eksperimentalni skupini pomembno izboljšala po končanem računalniškem kognitivnem treningu, v primerjavi s kontrolno skupino, ter v kolikšni meri. Preverjali smo učinke treninga na naslednja kognitivna področja: preklapljanje med mentalnimi seti, verbalno fluentnost, delovni in dolgotrajni spomin ter hitrost procesiranja informacij.

\section{Metoda}

\section{Udeleženci}

$\mathrm{V}$ raziskavo smo vključili učence od 4. do 9. razreda $\mathrm{z}$ lažjo motnjo $\mathrm{v}$ duševnem razvoju, opredeljeno $\mathrm{v}$ odločbi Komisije za usmerjanje otrok s posebnimi potrebami, ki obiskujejo eno izmed šol, ki izvaja prilagojen program $\mathrm{z}$ nižjim izobrazbenim standardom. Učenci so bili stari od 10 do 19 let. Naključno smo jih razporedili v eksperimentalno in kontrolno skupino, pri čemer smo upoštevali, da je bilo iz vsakega razreda v eksperimentalni skupini približno enako število učencev kot $\mathrm{v}$ kontrolni ter da je bilo iz vsakega razreda $\mathrm{v}$ eksperimentalni skupini približno enako število deklet in fantov kot v kontrolni skupini. V eksperimentalni skupini je bilo sprva 12 učencev, a smo nato enega učenca izključili iz raziskave zaradi daljše odsotnosti. Končni vzorec je tako sestavljal 21 učencev (10 deklet in 11 fantov, $M_{\text {starost }}=13,7$ leta, $S D=2,5$ leta). V eksperimentalni skupini je bilo 11 učencev (6 deklet in 5 fantov, $M_{\text {starost }}=14,1$ leta, $S D=2,7$ leta), v kontrolni skupini pa 10 (4 dekleta in 6 fantov, $M_{\text {starost }}=13,3$ leta, $S D=2,3$ leta). Štirje učenci so bili iz 4. razreda, 6 jih je bilo iz 5. in 6. razreda (5. in 6. razred sta na šoli združena), 6 iz 7. in 8. razreda (7. in 8. razred sta združena) ter 5 iz 9. razreda. Ena izmed udeleženk kontrolne skupine je bila v času testiranja dlje časa odsotna, zato smo zanjo pridobili le del podatkov (nevropsihološkega testiranja $\mathrm{z}$ njo nismo uspeli opraviti). Kontrolna in eksperimentalna skupina se na izhodiščnem testiranju nista statistično pomembno razlikovali $\mathrm{v}$ številu deklet in fantov, $\chi^{2}(1)=0,44, p=0,51$, ali v povprečni starosti, $t(19)=0,74$, $p=0,47, d=0,32$.

Nekateri učenci so imeli poleg lažje motnje v duševnem razvoju pridružene še druge motnje oziroma težave (zmerno izgubo sluha, lažjo govorno-jezikovna motnja, ADHD, lažjo oblika vedenjskih motenj), a ker gre pri vsaki od pridruženih motenj le za enega učenca s tovrstno motnjo, tega nismo posebej upoštevali pri analizi podatkov. V obeh skupinah je bilo število učencev s pridruženimi motnjami oziroma težavami približno enako.

\section{Pripomočki}

Za oceno kognitivnih funkcij smo uporabili različne teste: Test povezovanja, Reyjev slušno-verbalni test, Test verbalne fluentnosti in računalniško baterijo CogState.

\section{Nevropsihološki testi}

Test povezovanja (angl. Trail making test - TMT) je nevropsihološki instrument, ki daje informacije o številnih kognitivnih veščinah in ga je mogoče zelo hitro opraviti (testiranje traja 5-10 min). Ker nekateri udeleženci naše raziskave še niso dovolj dobro poznali vrstnega reda črk in številk, smo na list napisali črke in številke po vrstnem redu, da jim je služil kot opora pri reševanju naloge. Da smo omogočili enake testne pogoje za vse, smo list položili pred vse udeležence, torej tudi tiste, ki so poznali vrstni red številk in črk. Del A velja za test vizualnega iskanja in motorične 
hitrosti, medtem ko del B šteje tudi kot test višjih kognitivnih veščin, npr. mentalne fleksibilnosti (Crowe, 1998). Koeficienti zanesljivosti Testa povezovanja se gibljejo med 0,78 (Franzen idr., 1996) in 0,92 (Charter idr., 1987).

Reyjev avditorno verbalni test (angl. Rey Auditory Verbal Learning Test - RAVLT). Ena največjih prednosti tega testa je, da hkrati zagotavlja številne mere učenja in spomina (Wiens idr., 1988, citirano v: Vakil in Blachstein, 1993). S testom preverjamo kognitivne sposobnosti na področju slušno-besednega spomina, vpliv vaje na učenje, retroaktivno in proaktivno inhibicijo, ohranjanje podatkov $\mathrm{v}$ spominu (retencijo), vpliv distraktorjev na spominsko procesiranje ter razlikovanje med učenjem, priklicem in strategijo organizacije učenja. Testator $\mathrm{s}$ pomočjo tega testa dobi informacije, ki so ključne za razumevanje vrste in resnosti spominskih deficitov osebe. Test vsebuje listo A in B. V naši raziskavi smo postopek testiranja zaradi časovne omejitve nekoliko prilagodili. Listo A smo prebrali trikrat (preizkus I, II, III, da smo spremljali krivuljo učenja), nato smo prebrali listo $B$ in nazadnje je moral testiranec našteti besede, ki si jih je zapomnil s prve liste (preizkus IV). Rezultat vsakega priklica je bilo število pravilno priklicanih besed. Zabeležili smo rezultat preizkusa po interferenci (preizkusa IV) ter skupno pridobitev (vsoto preizkusov od I do III). Kot pri večini spominskih testov se tudi tu lahko kažejo učinki učenja (McCaffrey idr., 2000, citirano v: Lezak, 2012).

Test verbalne fluentnosti (angl. Verbal fluency test) je pogosto uporabljan nevropsihološki test, tako v kliničnih kot v eksperimentalnih okoljih (Troyer idr., 1997). Naloge verbalne fluentnosti dajejo podatke o verbalni produktivnosti, semantičnem spominu, jeziku in izvršilnih funkcijah ter se štejejo za občutljivo mero možganske disfunkcije (Lezak idr., 2004; Ramier in Hécaen, 1970). V naši raziskavi so učenci v času ene minute priklicali čim več besed na črko $\mathrm{M}$, pri čemer smo jim na začetku sporočili, naj se izogibajo imenom in priimkom; nato pa so v eni minuti priklicali še čim več živali na črko K. Točkovali smo le pravilne odgovore. Intruzije ali ponavljajoče besede ter različice znotraj iste vrste (npr. pri živalih) nismo vrednotili (glej npr. Peña-Casanova idr., 2009).

CogState je računalniška nevropsihološka baterija, ki ocenjuje številne kognitivne sposobnosti (Bangirana idr., 2015). Odkriva in spremlja osnovne kognitivne primanjkljaje, povezane s ključnimi nevrodegenerativnimi in psihiatričnimi motnjami, vključno z Alzheimerjevo boleznijo, poškodbo možganov, depresijo, multiplo sklerozo in shizofrenijo. Zasnovana je za večkratno uporabo $\mathrm{Z}$ minimalnimi učinki učenja (Cogstate, 2018). V standardni bateriji je na voljo več testov, $\mathrm{v}$ našo raziskavo pa smo vključili le tiste, ki so se nam zdeli primerni za populacijo učencev z lažjo motnjo $\mathrm{v}$ duševnem razvoju: Test učenja $\mathrm{s}$ priklicem poti v mrežnem labirintu (angl. Groton Maze Chase Test - GMCT), Test učenja mrežnega labirinta (angl. Groton Maze Learning Test - GMLT), Test zaznavanja (angl. Detection Test - DET), Test ena nazaj (angl. One Back Test - ONB) in Test asociativnega učenja parov (angl. Continuous Paired Associate Learning Test-CPAL). GMCT meri vidno-motorično kontrolo. Naloga testiranca je, da sledi tarči skozi labirint. Za oceno hitrosti vidnega procesiranja smo uporabili število pravilnih korakov na sekundo (mps).
Višje točke pomenijo boljšo izvedbo. GMLT meri izvršilne funkcije $\mathrm{z}$ uporabo paradigme učenja labirinta. Pri tem testu smo preverili vidno-prostorski dolgotrajni spomin, in sicer smo za mero uporabili skupno število napak pri poskusu učenja iste skrite poti pri petih zaporednih poskusih (ter), kjer nižje točke pomenijo boljšo izvedbo. DET meri hitrost procesiranja $\mathrm{z}$ uporabo enostavne paradigme reakcijskega časa. Na sredini zaslona je prikazana igralna karta, ki je obrnjena navzdol. Takoj, ko se karta razkrije, mora testiranec pritisniti gumb »Da«. za oceno hitrosti vidnega procesiranja smo uporabili mero odzivnega časa pravilnih zaznav karte (lmn; $\log _{10}$ transformiranega reakcijskega časa za pravilne odzive, opredeljen v ms), kjer nižje točke pomenijo boljšo izvedbo. ONB meri delovni spomin z uporabo paradigme n-nazaj. Na sredini zaslona je prikazana igralna karta, ki je obrnjena navzgor. Testiranec se mora odločiti, ali je karta enaka kot prejšnja karta. Za oceno delovnega spomina smo uporabili mero odzivnega časa pravilnega prepoznavanja in razvrščanja karte (lmn), pri čemer nižje točke pomenijo boljšo izvedbo, ter natančnost izvedbe naloge (acc), pri čemer višje točke pomenijo boljšo izvedbo. CPAL meri vidni spomin $\mathrm{z}$ uporabo paradigme asociativnega učenja parov. Pri tem testu se mora testiranec naučiti in si zapomniti slike, skrite pod različnimi mesti na zaslonu. Merimo skupno število napak, ki jih testiranec naredi skozi pridobivanje in učenje v sedmih ponovitvah (err). Nižje točke pomenijo boljšo izvedbo (Hammers idr., 2012).

\section{Računalniški kognitivni trening - virtualni labirint (RKT)}

Pri računalniškem kognitivnem treningu - virtualnem labirintu se posameznik s pomočjo tipkovnice giblje skozi različne poti labirinta in išče pravo pot do cilja. Naloga je na računalniškem zaslonu predstavljena s perspektive prve osebe, ki se giblje po tridimenzionalnem prostoru, in vključuje serijo medsebojno povezanih hodnikov in ulic s tremi razpoložljivimi potmi (levo, desno in naravnost) na vsakem križišču. Ena izmed treh poti, med katerimi se mora posameznik odločati na vsakem križišču, vodi do cilja, drugi dve pa vodita do slepih ulic. Na vsakem križišču sta na vogalih križišča (levo in desno) postavljeni fotografiji dveh različnih živali, ki sta posamezniku v pomoč pri orientaciji (skupno število živali v programu je 98). Posameznik dobi navodila, naj izbere pravo pot, kolikor hitro in učinkovito je mogoče, z namenom premikati se naprej do cilja. Ko doseže cilj, se zopet vrne na začetno točko, saj mora isto pot prehoditi še dvakrat brez napake, da lahko nadaljuje na naslednjo stopnjo. Vsaka napaka pomeni dodatno pot po istem labirintu. Udeleženci eksperimentalne skupine v naši raziskavi so lahko napredovali največ do labirinta $\mathrm{z}$ devetimi križišči (Lah, 2017).

Marusic idr. (2016) so v raziskavo vključili odrasle, ki so izvajali računalniški kognitivni trening - virtualni labirint, in ugotovili, da s treningom stimuliramo mesto $\mathrm{v}$ hipokampusu, intervencija pa vpliva na multipla nevronska področja $\mathrm{v}$ možganih, povezana $\mathrm{s}$ kognitivnimi veščinami, kot so izvršilne funkcije in spomin. 


\section{Postopek}

Pred intervencijo in po njenem zaključku (torej pred začetkom izvedbe prvega treninga in po zaključku zadnjega treninga) smo udeležence $\mathrm{v}$ kontrolni in eksperimentalni skupini testirali $\mathrm{z}$ nevropsihološkimi testi in računalniško baterijo CogState. Testiranje $\mathrm{z}$ nevropsihološkimi testi je potekalo individualno, testiranje $\mathrm{z}$ računalniško baterijo
CogState pa skupinsko (v skupini so bili trije do štirje učenci istega razreda). Med začetnim in končnim testiranjem smo $\mathrm{z}$ eksperimentalno skupino 12 -krat po $35 \mathrm{~min}$ izvedli računalniški kognitivni trening. Intervencija je potekala dvakrat tedensko. Potekala je skupinsko (v skupini so bili trije do štirje učenci istega razreda). Kontrolna skupina ni bila deležna intervencije. Sodelovanje je potekalo približno štiri mesece.

\section{Tabela 1}

Opisna statistika dosežkov eksperimentalne in kontrolne skupine na različnih nevropsiholoških testih in rezultati statističnih testov primerjav skupin

\begin{tabular}{|c|c|c|c|c|c|c|}
\hline \multirow[b]{2}{*}{ Spremenljivke } & \multicolumn{2}{|c|}{$\begin{array}{l}\text { Testiranje pred } \\
\text { kognitivnim } \\
\text { treningom }\end{array}$} & \multirow[t]{2}{*}{$\begin{array}{l}\text { Primerjava rezultatov med } \\
\text { skupinama na začetku }\end{array}$} & \multicolumn{2}{|c|}{$\begin{array}{l}\text { Testiranje po } \\
\text { kognitivnem } \\
\text { treningu }\end{array}$} & \multirow[t]{2}{*}{ Učinek treninga } \\
\hline & ES & KS & & ES & $\mathrm{KS}$ & \\
\hline \multicolumn{7}{|l|}{ TMT-B } \\
\hline$M$ & 157,6 & 181,7 & $U=43,00$ & 125,6 & 176,3 & $t(18)=-1,21$ \\
\hline$S D$ & 54,5 & 87,9 & $p=, 62, r=0,11$ & 40,4 & 79,7 & $p=, 24, d=-0,54$ \\
\hline \multicolumn{7}{|l|}{ VF-M } \\
\hline$M$ & 5,5 & 6,4 & $U=44,00$ & 7,2 & 7,2 & $t(18)=1,80$ \\
\hline$S D$ & 3,1 & 2,4 & $p=, 67, r=0,09$ & 3,2 & 2,7 & $p=, 09, d=0,81$ \\
\hline \multicolumn{7}{|l|}{ VF-K } \\
\hline$M$ & 4,6 & 4,8 & $t(18)=-0,31$ & 5,2 & 4,2 & $F(1,17)=4,06$ \\
\hline$S D$ & 2,0 & 1,2 & $p=, 76, d=-0,14$ & 1,7 & 1,1 & $p=, 06, \eta_{\mathrm{p}}{ }^{2}=0,19$ \\
\hline \multicolumn{7}{|l|}{ ONB (acc) } \\
\hline$M$ & 0,9 & 0,9 & $t(19)=0,49$ & 1,1 & 1,1 & $F(1,18)=0,51$ \\
\hline$S D$ & 0,2 & 0,3 & $p=, 63, d=0,21$ & 0,2 & 0,3 & $p=, 48, \eta_{\mathrm{p}}^{2}=0,03$ \\
\hline \multicolumn{7}{|l|}{ ONB (lmn) } \\
\hline$M$ & 3,0 & 3,0 & $t(19)=0,20$ & 3,0 & 3,0 & $F(1,18)=0,20$ \\
\hline$S D$ & 0,1 & 0,1 & $p=, 85, d=0,09$ & 0,1 & 0,1 & $p=, 66, \eta_{\mathrm{p}}^{2}=0,01$ \\
\hline \multicolumn{7}{|c|}{ AVLT - skupna pridobitev } \\
\hline$M$ & 20,9 & 19,4 & $t(18)=0,55$ & 24,4 & 19,2 & $F(1,17)=6,40$ \\
\hline$S D$ & 4,9 & 7,0 & $p=, 59, d=0,25$ & 5,7 & 7,9 & $\boldsymbol{p}=\mathbf{, 0 2}, \eta_{\mathrm{p}}^{2}=0,27$ \\
\hline \multicolumn{7}{|l|}{ AVLT-IV } \\
\hline$M$ & 4,9 & 5,2 & $U=46,00$ & 7,3 & 5,2 & $t(16)=2,29$ \\
\hline$S D$ & 2,7 & 3,4 & $p=, 78, r=0,06$ & 2,2 & 3,2 & $p=, \mathbf{0 4}, d=1,03$ \\
\hline \multicolumn{7}{|l|}{ GMLT (ter) } \\
\hline$M$ & 80,6 & 110,0 & $t(19)=-1,61$ & 77,8 & 76,3 & $F(1,18)=0,95$ \\
\hline$S D$ & 23,3 & 55,5 & $p=, 12, d=-0,70$ & 22,0 & 16,0 & $p=, 34, \eta_{\mathrm{p}}^{2}=0,05$ \\
\hline \multicolumn{7}{|l|}{ CPAL (err) } \\
\hline$M$ & 122,2 & 108,4 & $t(19)=0,39$ & 76,2 & 95,1 & $F(1,18)=3,10$ \\
\hline$S D$ & 63,0 & 97,5 & $p=, 70, d=0,17$ & 47,5 & 78,7 & $p=, 09, \eta_{\mathrm{p}}^{2}=0,15$ \\
\hline \multicolumn{7}{|l|}{ TMT-A } \\
\hline$M$ & 65,3 & 66,9 & $t(18)=-0,17$ & 48,1 & 62,1 & $F(1,17)=6,90$ \\
\hline$S D$ & 22,4 & 20,1 & $p=, 87, d=-0,08$ & 15,3 & 18,1 & $\boldsymbol{p}=, \mathbf{0 2}, \eta_{\mathrm{p}}^{2}=0,29$ \\
\hline \multicolumn{7}{|l|}{ DET (lmn) } \\
\hline$M$ & 2,6 & 2,6 & $t(19)=-0,33$ & 2,6 & 2,7 & $U=46,0$ \\
\hline$S D$ & 0,1 & 0,1 & $p=, 75, d=-0,14$ & 0,1 & 0,1 & $p=, 523, d=-0,28$ \\
\hline \multicolumn{7}{|l|}{ GMCT (mps) } \\
\hline M & 1,2 & 1,2 & $t(19)=0,18$ & 1,3 & 1,3 & $F(1,18)=0,17$ \\
\hline$S D$ & 0,3 & 0,5 & $p=, 86, d=0,08$ & 0,2 & 0,4 & $p=, 68, \eta_{\mathrm{p}}^{2}=0,01$ \\
\hline
\end{tabular}

Opombe: $\mathrm{ES}=$ eksperimentalna skupina, $\mathrm{KS}=$ kontrolna skupina, TMT-B = Test povezovanja - del B, VF-m = verbalna fluentnost - besede, ki se začnejo s črko M, VF-K = verbalna fluentnost - živali na črko K, ONB = Test ena nazaj, AVLT = Reyjev slušno-verbalni test, GMLT = Test učenja mrežnega labirinta, $\mathrm{CPAL}=$ Test asociativnega učenja parov, TMT-A = Test povezovanja - del A, DET = Test zaznavanja, GMCT $=$ Test učenja s priklicem poti $\mathrm{v}$ mrežnem labirintu, acc $=$ točnost izvedbe naloge, $\operatorname{lmn}=$ hitrost izvedbe naloge $\left(\mathrm{v} \log _{10} \mathrm{~ms}\right)$, ter $=\mathrm{skupno}$ število napak, err = število napak, mps = gibi na sekundo. 


\section{Statistična obdelava podatkov}

Podatke smo statistično obdelali $\mathrm{Z}$ računalniškim programom SPSS, verzija 21. Naredili smo $t$-test za neodvisne vzorce oziroma Mann-Whitneyjev $U$ test (pri spremenljivkah, ki niso izpolnjevale predpostavk za izvedbo $t$-testa), da bi preverili, ali obstajajo med eksperimentalno in kontrolno skupino statistično pomembne razlike $\mathrm{v}$ prvem merjenju. Za preverjanje enakosti skupin po spolu pa smo uporabili Pearsonov $\chi^{2}$ preizkus. Za vsako skupino posebej smo pri vseh spremenljivkah naredili tudi parni $t$-test oziroma Wilcoxonov test predznačenih rangov (pri spremenljivkah, ki niso izpolnjevale predpostavk za izvedbo $t$-testa), da smo preverili, ali pride do statistično pomembne razlike med dosežki, izmerjenimi v času pred in času po intervenciji.

Učinkovitost kognitivnega treninga smo pri vsaki spremenljivki preverjali $\mathrm{z}$ univariatno analizo kovariance (ANCOVO), kjer smo kot odvisno spremenljivko obravnavali rezultat na končnem testiranju, kot neodvisno spremenljivko pa skupino. Za kovariat smo uporabili rezultate s prvega merjenja. Pri spremenljivkah, ki niso izpolnjevale vseh predpostavk za izvedbo ANCOVE (oblika porazdelitve se je odklanjala od normalne, prisotni so bili pomembni osamelci, kršena je bila predpostavka linearne povezanosti kovariata $\mathrm{z}$ odvisno spremenljivko ali predpostavka homoskedastičnosti), smo izračunali odstotek spremembe po enačbi ((drugo testiranje - prvo testiranje)/prvo testiranje) $\times 100$. Nato smo preverili, ali se odstotek spremembe porazdeljuje normalno in na podlagi tega naredili $t$-test za neodvisne vzorce oziroma Mann-Whitneyjev $U$ test. Vse hipoteze smo testirali pri 5-odstotni ravni tveganja.

\section{Slika 1}

Povprečen rezultat na meri AVLT - skupna pridobitev pri prvem in drugem testiranju za eksperimentalno in kontrolno skupino

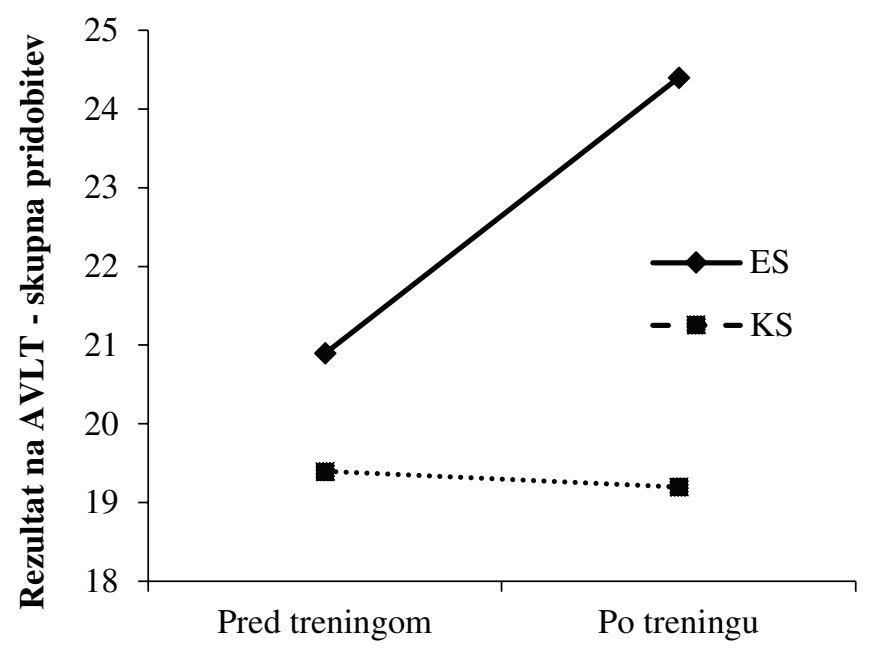

Čas merjenja

\section{Rezultati}

Dosežki (aritmetična sredina in standardna deviacija) na vsakem testu pred in po računalniškem kognitivnem treningu za eksperimentalno in kontrolno skupino so predstavljeni v Tabeli 1. Predstavljene so tudi primerjave skupin na začetnem testiranju ter rezultati ANCOVE oziroma $t$-testa za neodvisne vzorce ali Mann-Whitneyjevega $U$ testa na podlagi izračuna odstotka spremembe.

Kot vidimo $\mathrm{v}$ tabeli 1 , so se po treningu pokazale pomembno večje izboljšave pri eksperimentalni skupini $\mathrm{v}$ primerjavi s kontrolno skupino pri spremenljivkah AVLT - skupna pridobitev, AVLT-IV in TMT-A. Post hoc analize so pokazale, da je prišlo pri spremenljivki AVLT - skupna pridobitev do pomembnega izboljšanja dosežka pri eksperimentalni skupini, $t(10)=-4,31, p=, 002$, $d=0,63$, ne pa tudi pri kontrolni skupini, $t(8)=0,19, p=, 86$, $d=0,03$. Pri AVLT-IV je prišlo do pomembnega izboljšanja pri eksperimentalni skupini, $t(10)=-3,56, p=, 005$, $d=0,95$, ne pa tudi pri kontrolni skupini, $Z=-0,18, p=0,86$, $r=0,06$. Pri TMT-A je prišlo do pomembnega izboljšanja pri eksperimentalni skupini, $t(10)=3,37, p=, 007, d=0,84$, pri kontrolni skupini pa ne, $t(8)=1,66, p=, 14, d=0,24$.

\section{Razprava}

Trening je pomembno vplival na rezultate pri spremenljivkah AVLT - skupna pridobitev (meri skupnega števila priklicanih besed, vsota preizkusov od I do III), AVLT-IV (preizkusu po interferenci) in TMT-A (kjer se

\section{Slika 2}

Povprečen rezultat pri nalogi AVLT-IV pri prvem in drugem testiranju za eksperimentalno in kontrolno skupino

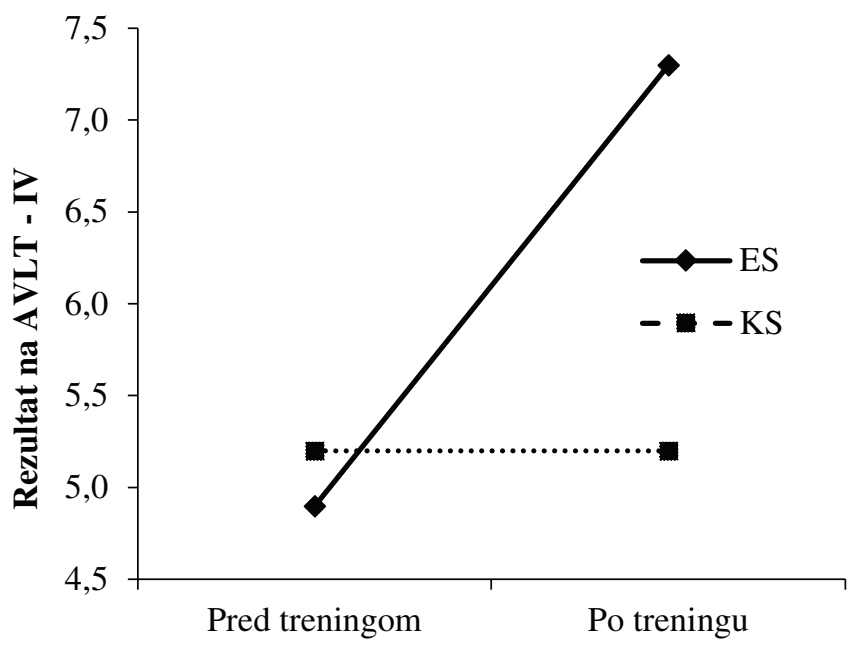

Čas merjenja 


\section{Slika 3}

Povprečen čas rě̌evanja testa TMT-A pri prvem in drugem testiranju za eksperimentalno in kontrolno skupino

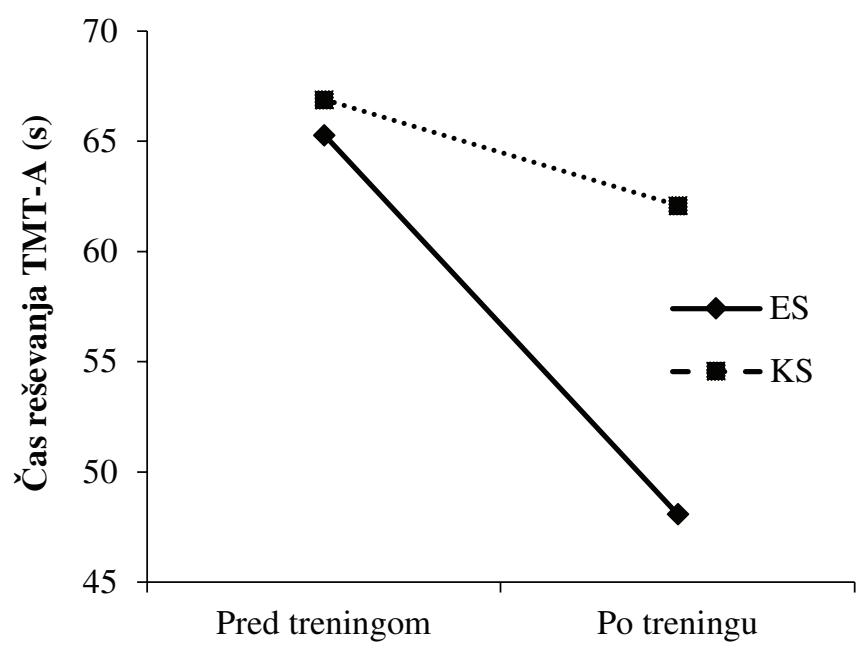

Čas merjenja

preverja motorična hitrost), statistični pomembnosti pa se je rezultat približal še pri nalogi verbalne fluentnosti živali na k.

Pokazalo se je, da je imel trening večje učinke na verbalni spomin in učenje kot na vidno-prostorski spomin, kar je presenetljivo $\mathrm{z}$ vidika, da sam trening ni direktno vključeval verbalne komponente. To, da je imel trening učinke na verbalno področje, kaže na prenos učinkov treninga med kognitivnimi področji. Do podobnih ugotovitev o prenosu učinkov treninga med kognitivnimi konstrukti so prišli tudi Söderqvist idr. (2012), ki so v študiji ravno tako raziskovali učinke treninga pri otrocih $\mathrm{z}$ motnjo $\mathrm{v}$ duševnem razvoju. $\mathrm{V}$ njihovi študiji je trening, ki je zajemal samo vidno-prostorske naloge, privedel do izboljšav pri nalogah, ki ocenjujejo verbalni delovni spomin in jezikovne funkcije. Niso pa preverjali učinkov na dolgotrajni spomin. Tudi druge študije, ki so preučevale učinke kognitivnega treninga pri otrocih $\mathrm{z}$ motnjo v duševnem razvoju, so se osredotočale predvsem na delovni spomin.

Naši rezultati niso povsem $\mathrm{v}$ skladu $\mathrm{z}$ ugotovitvami raziskave S. Lah (2017), ki je ugotavljala učinke enakega treninga, kot smo ga uporabili v naši študiji, pri otrocih $\mathrm{s}$ specifičnimi učnimi težavami. V njeni raziskavi se je namreč na merah spomina in učenja pri eksperimentalni skupini pri večini spremenljivk pokazalo večje izboljšanje od prvega do drugega merjenja kot pri kontrolni skupini, a izboljšanje ni bilo pri nobeni spremenljivki statistično pomembno. Dobro bi bilo raziskati, ali morda tovrsten trening vendarle vključuje verbalno komponento. Učenci si lahko namreč pri hoji skozi labirint govorijo navodila (npr. "prvo križišče levo, drugo desno«), kar bi lahko krepilo dolgotrajni verbalni spomin.

Pri dosežkih na merah hitrosti procesiranja se je edini pomemben učinek treninga pokazal pri Testu povezovanja - del A. Zanimivo je, da je trening statistično pomembno vplival le na rezultate tega dela testa TMT. Ta del preverja zgolj motorično hitrost, medtem ko na rezultate dela $\mathrm{B}$ tega testa, ki zajema tudi preklapljanje med mentalnimi seti in je $\mathrm{s}$ tega vidika bolj zahteven, trening ni imel učinka. Rezultati niso v skladu z rezultati raziskave S. Lah (2017), ki je izvajala enak trening pri otrocih s specifičnimi učnimi težavami, saj se v njeni raziskavi ni pokazalo statistično pomembno večje izboljšanje rezultatov eksperimentalne skupine v primerjavi s kontrolno skupino pri nobeni izmed spremenljivk, s katerimi je merila hitrost procesiranja.

Glavno prednost naše raziskave vidimo $\mathrm{v}$ tem, da smo $\mathrm{v}$ raziskavo vključili le otroke z lažjo motnjo v duševnem razvoju, medtem ko so drugi avtorji, ki so preučevali vpliv računalniškega kognitivnega treninga pri otrocih $\mathrm{z}$ motnjo $\mathrm{v}$ duševnem razvoju, največkrat vključili tudi otroke $\mathrm{z}$ nižjim inteligentnostnim količnikom, pri katerih ne govorimo več o lažji motnji, ampak so prisotni večji primanjkljaji. Izmed pregledanih študij so le v dveh študijah (Delavarian idr., 2015; Teleb idr., 2016) avtorji navedli, da so v študijo vključili le otroke $\mathrm{z}$ lažjo motnjo v duševnem razvoju. Prednost naše študije je tudi $\mathrm{v}$ tem, da je trening potekal pod nadzorom raziskovalke. $\mathrm{V}$ nekaterih študijah namreč tem pogojem ni zadoščeno. Tudi to, da je trening potekal preko računalnika, lahko razumemo kot prednost, saj so računalniški treningi programirani tako, da otroka nagrajujejo na dosleden način.

Pomanjkljivost naše raziskave je majhnost vzorca. Pri več spremenljivkah se je pokazalo, da je eksperimentalna skupina od prvega do drugega testiranja izboljšala rezultat, vendar izboljšanje ni bilo statistično pomembno večje kot pri kontrolni skupini. Morda bi ob večjem vzorcu rezultat dosegel statistično pomembnost. Bolj reprezentativen vzorec bi dosegli tudi, če bi v vzorec zajeli otroke iz različnih šol, regij. Udeleženci naše raziskave so namreč obiskovali isto šolo. Dobro bi bilo tudi vključiti aktivno kontrolno skupino, da bi lahko izločili morebitni učinek placeba. Smiselno bi bilo tudi preveriti dolgoročne učinke treninga.

Kot prednost in hkrati pomanjkljivost študije pa lahko izpostavimo dejstvo, da je šlo za skupinski trening. Prednost je $\mathrm{v}$ tem, da so bili udeleženci bolj motivirani za doseganje uspehov pri treningu, saj so se primerjali $\mathrm{z}$ drugimi udeleženci, po drugi strani pa je to slabost, saj so udeleženci motili drug drugega med izvajanjem treninga.

\section{Zaključek}

Pomembna ugotovitev naše raziskave je, da je računalniški kognitivni trening pri otrocih $\mathrm{z}$ lažjo motnjo izvedljiv. Kljub temu, da so udeleženci prišli do nekoliko nižje ravni zahtevnosti labirinta kot v študiji S. Lah (2017), ki je izvajala enak trening pri otrocih s specifičnimi učnimi težavami, so rezultati obetavni. Glede na to, da nekatere študije poročajo o upadu motivacije udeležencev med treningom, nas je skrbelo, da bo trening za otroke $\mathrm{z}$ lažjo motnjo $\mathrm{v}$ duševnem razvoju pretežak in bo to vodilo $\mathrm{v}$ upad motivacije za nadaljnje sodelovanje pri treningu. Pokazalo se je ravno obratno, saj so udeleženci z veseljem sodelovali pri treningu in se veselili uspehov. Zdi se, da je k temu pripomogla tudi struktura treninga. Trening je namreč sestavljen tako, da posameznika na koncu vsake poti po labirintu čaka pokal, tudi če je pri iskanju poti storil kakšno napako in bo moral zato še enkrat ponoviti pot, preden bo lahko napredoval na višjo raven. 
Statistično pomembni učinki treninga pri nalogah AVLT skupna pridobitev, AVLT-IV ter TMT - del A ter nakazani pozitivni učinki treninga pri nekaterih drugih nalogah so zelo spodbudni, saj kažejo, da je do določene mere možno trenirati kognitivne funkcije pri otrocih $\mathrm{z}$ lažjo motnjo $\mathrm{v}$ duševnem razvoju. Že Delavarian idr. (2015) ugotavljajo, da bi glede na rezultate njihove študije izvajanje treninga delovnega spomina $\mathrm{v}$ posebnih šolah, kjer se šolajo otroci $\mathrm{z}$ motnjo $\mathrm{v}$ duševnem razvoju, pod nadzorom usposobljenega učitelja lahko vodilo do zelo učinkovitega izboljšanja delovnega spomina in sposobnosti učenja. Za oblikovanje jasnih zaključkov bi bile potrebne dodatne študije, ki bi poleg kratkoročnih preučevale še dolgoročne učinke treninga in prenos učinkov na vsakodnevno življenje, saj je zaenkrat študij, ki bi preučevale učinkovitost kognitivnega treninga pri otrocih z lažjo motnjo v duševnem razvoju, zelo malo.

\section{Literatura}

Bangirana, P., Sikorskii, A., Giordani, B., Nakasujja, N. in Boivin, M. J. (2015). Validation of the CogState battery for rapid neurocognitive assessment in Ugandan school age children. Child and Adolescent Psychiatry and Mental Health, 9(38), 1-7.

Barič, M. (2009). Struktura modela svetovanja za ranljivo skupino oseb s posebnimi potrebami - Osebe z lažjo motnjo $v$ duševnem razvoju [The structure of the model of counseling for the vulnerable group of individuals with special needs - Individuals with mild cognitive disability] (poročilo operacije Razvoj modelov svetovanja za ranljive skupine). Ministrstvo RS za šolstvo in šport. http://mizs. arhiv-spletisc.gov.si/fileadmin/mizs.gov.si/pageuploads/ podrocje/odrasli/Gradiva ESS/CVZU/razvoj modelov/ CVZU_7MODELI_Struktura_lazja.pdf

Bergman Nutley, S., Soderqvist, S., Bryde, S., Thorell, L. B., Humphreys, K. in Klingberg,T. (2011). Gains in fluid intelligence after training non-verbal reasoning in 4-year-old children: A controlled, randomized study. Developmental Science, 14(3), 591-601.

Brown, T. E. (2005). Attention deficit disorder: The unfocused mind in children and adults. Yale University Press.

Carpenter, P. A., Just, M. A. in Shell, P. (1990). What one intelligence test measures: A theoretical account of the processing in the Raven Progressive Matrices Test. Psychological Review, 97(3), 404-431.

Charter, R. A., Adkins, T. G., Alekoumbides, A. in Seacat, G. F. (1987). Reliability of the WAIS, WMS, and Reitan Battery: Raw scores and standardized scores corrected for age and education. International Journal of Clinical Neuropsychology, 9, 28-32.

Cogstate. (2018). Cogstate Research Battery. https://www. cogstate.com/academic-research/

Crowe, S. F. (1998). The differential contribution of mental tracking, cognitive flexibility, visual search, and motor speed to performance on parts A and B of the Trail Making Test. Journal of Clinical Psychology, 54(5), 585-591.
Danielsson, H., Zottarel, V., Palmqvist, L. in Lanfranchi, S. (2015). The effectiveness of working memory training with individuals with intellectual disabilities - A metaanalytic review. Frontiers in Psychology, 6, 1-10.

Dawson, P. in Guare, R. (2009). Executive Skills: The Hidden Curriculum. Principal Leadership, 9(7), 10-14.

Delavarian, M., Bokharaeian, B., Towhidkhah, F. in Gharibzadeh, S. (2015). Computer-based working memory training in children with mild intellectual disability. Early Child Development and Care, 185(1), 66-74.

Franzen, M. D., Paul, D. in Iverson, G. L. (1996). Reliability of alternate forms of the Trail Making Test. The Clinical Neuropsychologist, 10, 125-129.

Hammers, D., Spurgeon, E., Ryan, K., Persad, C., Barbas, N., Heidebrink, J., Darby, D. in Giordani, B. (2012). Validity of a brief computerized cognitive screening test in dementia. Journal of Geriatric Psychiatry and Neurology, 25(2), 89-99.

Holmes, J., Gathercole, S. E. in Dunning, D. L. (2009). Adaptive training leads to sustained enhancement of poor working memory in children. Developmental Science, 12(4), F9-F15.

Klingberg, T. (2010). Training and plasticity of working memory. Trends in Cognitive Sciences, 14(7), 317-324.

Klingberg, T., Fernell, E., Olesen, P. J., Johnson, M., Gustafsson, P., Dahlström, K., Gillberg, C. G., Forssberg, H. in Westerberg, H. (2005). Computerized training of working memory in children with ADHD: A randomized, controlled trial. Journal of the American Academy of Child and Adolescent Psychiatry, 44(2), 177-186.

Lah, S. (2017). Kognitivni računalniški trening kot dopolnitev dodatne strokovne pomoči in njegova učinkovitost pri učencih s posebnimi potrebami [Cognitive computer training as a completion of additional professional support and its effectiveness for pupils with special needs] [Magistrsko delo, Univerza v Mariboru, Filozofska fakulteta]. Digitalna knjižnica Univerze v Mariboru. https://dk.um.si/Dokument.php?id=120606

Lezak, M. (2012). Neuropsychological assessment. Oxford University Press.

Lezak, M. D., Howieson, D. B. in Loring, D. W. (2004). Neuropsychological assessment (4. izd.). Oxford University Press.

Marinč, D., Burnik, F., Vališer, A., Barborič, K., Potočnik Dajčman, N. in Dretnik, F. (2015). Otroci z motnjami v duševnem razvoju. V N. Vovk-Ornik (ur.), Kriteriji za opredelitev vrste in stopnje primanjkljajev, ovir oz. motenj otrok s posebnimi potrebami (str. 6-7). Zavod RS za šolstvo.

Marusic, U., Giordani, B., Moffat, S., Petrič, M., Dolenc, P., Pišot, R. in Kavcic, V. (2016). Computerized cognitive training during physical inactivity improves executive functioning in older adults. Aging Neuropsychology and Cognition, 25(1), 1-21.

Miyake, A., Friedman, N. P., Rettinger, D. A., Shah, P. in Hegarty, M. (2001). How are visuospatial working memory, executive functioning, and spatial abilities related? A latent-variable analysis. Journal of Experimental Psychology: General, 130(4), 621-640. 
Moalli, E. (2006). Conoscenze sulla memoria e prestazioni di memoria in individuicon sindrome di Down e con sviluppo tipico: Effetti di training di breve durata [Knowledge about memory and memory performance in individuals with Down syndrome and with typical development: Effects of short duration training] [Neobjavljenja doktorska disertacija]. Univerza v Padovi.

Moalli, E., Rota Negroni, S. in Vianello, R. (2004). Conoscenze sulla memoria eprestazioni di memoria in ragazzi con sindrome di Down: Effetti di due diversitraining di breve durata [Knowledge about memory and memory performance in boys with Down syndrome: Effects of two different short-term trainings]. Giornale Italiano delle Disabilitá, 3, 23-40.

Peña-Casanova, J., Quiñones-Úbeda, S., Gramunt-Fombuena, N., Quintana-Aparicio, M., Aguilar, M., Badenes, D., Cerulla, N., Molinuevo, J. L., Ruiz, E., Robles, A., Sagrario Barquero, M., Antunez, C., Martinez-Parra, C., Frank-Garcia, A., Fernandez, M., Alfonso, V., Sol, J. M. in Blesa, R. (2009). Spanish Multicenter Normative Studies (NEURONORMA Project): Norms for Verbal Fluency Tests. Archives of Clinical Neuropsychology, 24(4), 395-411.

Ramier, A. M. in Hécaen, H. (1970). Role respectif des atteintes frontales et de la late 'ralisation le sionnelle dans les de'ficits de la fluence verbale [Respective role of frontal impairment and lesion lateralization in verbal fluency deficits]. Revue Neurologique, 132, 17-22.

Salthouse, T. A., Fristoe, N., McGuthry, K. E. in Hambrick, D. Z. (1998). Relation of task switching to speed, age, and fluid intelligence. Psychology and Aging, 13(3), 445-461.

Söderqvist, S., Nutley, S. B., Ottersen, J., Grill, K. M. in Klingberg, T. (2012). Computerized training of nonverbal reasoning and working memory in children with intellectual disability. Frontiers in Human Neuroscience, 6, 200-207.

Teleb, A., Mohamed, W. in Elbert, T. (2016). Does enhancing visual perception in mild intellectually disabled children transfer to other skills? European Proceedings of Social and Behavioural Sciences (EpSBS): ICEEPSY 2016, 16, članek 41, 391-402.

Thorell, L. B., Lindqvist, S., Berman Nutley, S., Bohlin, G. in Klingberg, T. (2009). Training and transfer effects of executive functions in preschool children. Developmental Science, 12(1), 106-113.

Troyer, A. K., Moscovitch, M. in Winocur, G. (1997). Clustering and switching as two components of verbal fluency: Evidence from younger and older healthy adults. Neuropsychology, 11(1), 138-146.

Vakil, E. in Blachstein, H. (1993). Rey Auditory-Verbal Learning Test: Structure analysis. Journal of Clinical Psychology, 49(6), 883-890.

Van der Molen, M. J., Van Luit, J. E. H., Van der Molen, M. W., Klugkist, I. in Jongmans, M. J. (2010). Effectiveness of a computerised working memory training in adolescents with mild to borderline intellectual disabilities. Journal of Intellectual Disability Research, 54(5), 433-447. van 't Hooft, I., Andersson, K., Bergman, B., Sejersen, T., von Wendt, L. in Bartfai, A. (2007). Sustained favorable effects of cognitive training in children with acquired brain injuries. NeuroRehabilitation, 22(2), 109-16. 